\title{
AUTONOMIC NEUROPATHY IN DIABETES MELLITUS
}

\author{
By HARRY KeEN, M.B., M.R.C.P. \\ Research Fellow, The Medical Unit, St. Mary's Hospital and Clinical Assistant to the Diabetic Clinic, \\ King's College Hospital, London
}

Abnormalities of the nervous system were recognized early as part of the picture of diabetes mellitus. Following Claude Bernard's demonstration of 'piqûre diabetes' (I849), it was thought for a time that neurological disturbances might be responsible for persisting hyperglycaemia in man. By the end of the Igth century, however, it was clearly established that disease of the nervous system was a consequence of diabetes and not a cause of it. Little has been added to the clinical descriptions made then (Auché, I890; Pavy, 1885). An exception has been the growing realization that early and wide involvement of the autonomic nervous system may occur.

It was Rundles, in a classical study of diabetic neuropathy (1945), who first drew together a group of disorders occurring in diabetics which could reasonably be attributed to disease of the autonomic nervous system. In certain of these disorders, subsequent investigation has confirmed his view, as, for example, in the abnormal vascular responses to changes in body temperature and position, and disturbed control of sweating and piloerection. In others, such as the development of Charcot's joints, 'trophic' skin changes and the accumulation of oedema, the causal role of autonomic disease has been strongly challenged. For the most part, however, the claim has as yet been neither proven nor refuted; and into this category come such manifestations as ' diabetic diarrhoea,' sexual impotence and failure of ejaculation in males, atonic paralysis of the bladder, gastric retention and pupillary changes.

The aim of this account is to provide a clinical outline of each of these disorders and briefly to review the evidence implicating the autonomic nervous system. Though a clear understanding of the pathogenesis and treatment of diabetic neuropathy is still lacking (Shuman and Gilpin, 1954; Goodman, 1955), current views will also be presented where appropriate.

\section{Abnormalities in the Legs}

In the legs, disease of the autonomic nerves may be most clearly inferred from the abnormal reactions of the skin blood vessels, sweat glands and piloerector muscles to heating and cooling of the body. The maintenance of a steady internal body temperature requires the reflex operation of skin mechanisms to retain or dispel heat as occasion demands (Pickering, r958). Thus, cooling the body leads to a decrease in blood flow through the skin, while heating it leads to an increase, with sweating as body temperature rises, changes which are mediated through the sympathetic nerves. Diabetics with peripheral nerve disorder show abnormalities of body temperature (Jordan, 1936) and the absence of sweating in the limbs is ofter noticed in particular by patients who, previouslyo had perspired profusely.

Of the various methods available for gauging variations in skin blood flow, measurement of skin temperature has been most widely used in the investigations in diabetics. Most workers have found that the resting skin temperature in the foot is abnormally high, equalling or exceeding hand temperature, and that it fails to fall when the body is cooled (Shumacker, r942; Rundles, r945; Martin, 1953; Odel, 1955). Martin also described a group of patients with a low resting skin temperature in the feet which failed to rise after body heating. He excluded vascular occlusion as a cause by producing a rise to normal temperatures with intravenous priscol, and he invoked a disturbance selectively affecting vasodilator fibres to explain his findings. This explanation is, however, challenged by Barany (1955), who produced evidence that persistent vasoconstriction might be due to slow disposal of locally formed noradrenaline, or to hypersensitivity of 'sympathectomized' vessels to vasoconstrictor substances (Cannon and Rosenblueth, 1949); these results should be borne in mind when interpreting the findings of other workers who claim to have demonstrated ' small vessel' disease in diabetics on the basis of impaired responses to vasodilator stimuli (Megibow et al., 1953; Mendlowitz et al., 1953; Handelsman et al., 1952). 


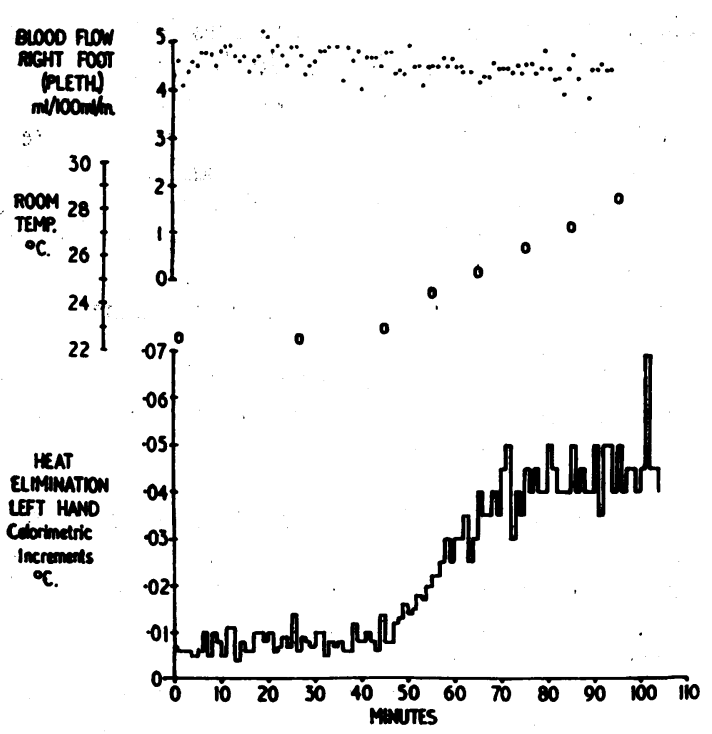

Fic. r.-Effect of general body heating upon blood flow in the right foot and heat elimination from the left hand.

\section{Case Report I (429268)}

Male clerk, aged 32 (1954). Patient of Professor G. W. Pickering.

History. Two years' loss of weight and lassitude. For one year severe but intermittent diarrhoea, becoming persistent, with up to 14 watery stools in 24 hours; diarrhoea chiefly nocturnal, sometimes with incontinence. Numbness in legs. Diabetes diagnosed nine months ago; treated adequately with diet and 50 units Lente insulin daily. No improvement of diarrhoea with fat-free diet and folic acid. Difficulty in starting urination; impotence (failure of erection) for three months.

Examination. Skin of trunk, legs and feet dry, with pitting oedema at ankles. Pain and temperature perception impaired below costal margin, and light touch over feet. Left knee jerk absent, but the right and both ankle jerks present on reinforcement. Cranial and arm nerves normal. Fundi: many ' microaneurysms' and flecks of exudate. B.P. lying $120 / 90$, after 10 minutes' standing 90/72, lying again $160 / 110$.

Investigations. Hb 95 per cent. Urine, no protein or pus, sterile. Plasma proteins, 6.3 g./100 ml., albumin 4.4 g., globulin $\mathrm{I} .9 \mathrm{~g}$. Blood urea, $37 \mathrm{mg} . / 100 \mathrm{ml}$. No faecal pathogens. Sigmoidoscopy normal. Three-day fat balance (September 1954), 87 per cent. absorption; (December 1954), 94 per cent. absorption.

A starch and iodine sweating test showed much diminished thermally-induced sweating over the front of the trunk and both legs.

Studies of skin blood flow were made in this
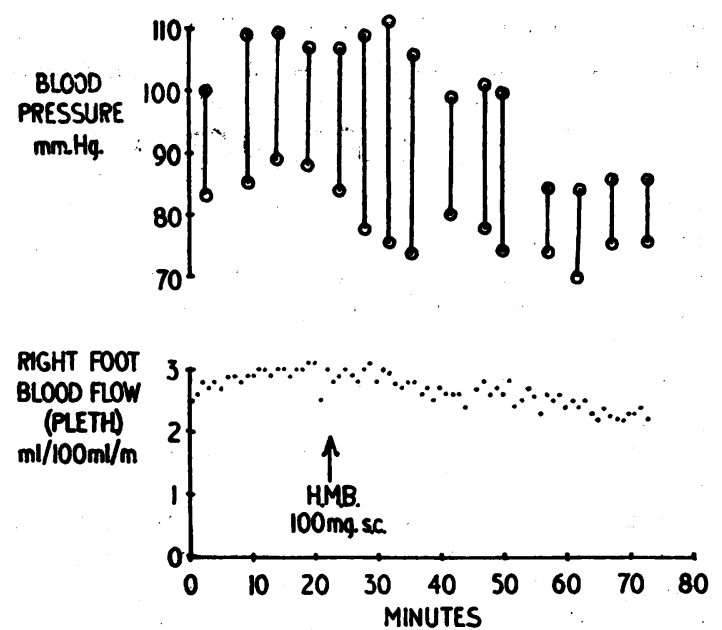

Fig. 2.-Effect of Hexamethonium upon blood flow in the right foot.

patient by Dr. E. S. Snell, using the modified Stewart calorimeter (Greenfield and Scarborough, 1949) and a foot plethysmograph; with his permission, some of the data (Figs. I and 2) are presented here.

Fig. I shows the effect of general body heating on blood flow in the right foot, measured plethysmographically, and the simultaneous changes inco heat elimination from the left hand, using the? calorimeter. As body temperature rises, so does heat elimination from the hand, but the foot blood flow, instead of rising also, falls slightly. Blood pressure remained constant.

Fig. 2 shows the effect of the administration of roo mg. hexamethonium bromide subcutaneously upon the blood pressure and the foot blood flow, measured by plethysmography. In the normal, hexamethonium releases vasomotor tone in the legs and blood flow increases (Hamilton et al., 1954). In this patient, however, the flow fell passively with the blood pressure. This shows clearly that alterations in vascular calibre can be inferred from changes in blood flow only if the pressure remains constant; and this is unlikely to obtain where unpleasant procedures are involved.

In the case described above and in others the normal vascular response in the arms proves that the central temperature receptor (Pickering, 1958) is functioning and places the lesion somewhere in the efferent sympathetic pathway to the legs.

In addition to this ' central ' reflex response to body heating, Kerslake and Cooper (1950) have described a reflex vasodilatation in the skin in response to surface warming elsewhere and independent of a general rise in body temperature. Thus, shortly after a radiant heat source is shone upon the leg of the normal subject, there is an 
increase in hand blood flow. This response is abolished by sympathectomy of the heated area (Cooper and Kerslake, I953), suggesting that sympathetic fibres carry the sensory impulses. Recently Coles (1958) has shown that, in patients with diabetic neuropathy, this radiant heat response is either reduced or absent. The hand vessels still dilate normally with general body heating, however, demonstrating an intact efferent pathway.

The experimental evidence quoted above suggests that, in the diabetic, sympathetic fibres carrying both afferent and efferent impulses are affected.

Extensive disease of sympathetic fibres to the legs may exist without pain or paraesthesiae (Barany and Cooper, 1956), but the case history which follows suggests that symptoms may be related to abnormalities in vascular control.

Case Report 2 (504196)

Male Army officer, aged 34 (1958). Patient of Professor C. Rob.

History. Thirst, weight loss and recurrent skin sepsis for five years. Pain in feet one year. Diabetes diagnosed four months ago; fairly well controlled on diet and 60 units Lente insulin daily. Ten weeks ago attacks of warmth, redness and burning of feet, becoming persistent and unbearably intense. Relieved only by elevation or ice-water cooling of feet; analgesics and lumbar sympathetic block ineffective. Bowels, bladder and potency normal; absent sweating of legs and feet.

Examination. Skin of legs smooth, shiny, tense and hairless, becoming red when hung down. Small septic lesions on soles. All foot pulses palpable. Elevation of legs followed by pallor and fine wrinkling of skin with emptying of distended veins. Left ankle jerk diminished, right absent; others normal. Temperature sensation lost over feet, and that of pain, position and vibration impaired to knees. Calves tender and soles hypersensitive. Persistent regular tachycardia I IO to 120/min., not slowed by carotid compression. B.P. II $5 / 80$.

Investigations. Blood count, plasma proteins, electrolytes, blood urea and liver function tests normal. Low renal threshold (<100 mg./100 ml. blood) glycosuria; no proteinuria.

Effect of dependency of legs. Immediate dusky reddening of feet with cold skin. After four minutes, appearance of bright red, warm sore areas. Whole foot warm and skin tense with burning pain at eight minutes, becoming maximal at II minutes. On re-elevating feet, pallor and wrinkling of skin rapidly reappeared.

Effect of venous obstruction in left leg. Pneumatic cuff at $80 \mathrm{~mm}$. $\mathrm{Hg}$ pressure applied to thigh of elevated left leg. After io minutes left foot congested, cool and uncomfortable, but no pain.

Effect of arterial obstruction in left leg. Left thigh cuff applied at $200 \mathrm{~mm}$. $\mathrm{Hg}$ with both legs elevated. Left foot pulses impalpable. Both legs lowered; at five minutes, with right foot congested and sore, and left foot pallid, cuff was deflated. Followed immediately by bright reddening of the left foot with immediate severe pain, lessened by elevating leg.

' $G$ '-suit experiments. Application of inflatable suit relieved pain in legs-down position only when pressure exceeded $100 \mathrm{~mm}$. $\mathrm{Hg}$.

Progress. Ligation of left common femoral and right external iliac arteries by Professor C. Rob eased pain only slightly. Persistent pain and spreading sepsis in feet necessitated re-establishment of ligated vessels and bilateral below-knee amputation of legs.

Only limited conclusions can be drawn from the observations made in this case; the pain appeared to depend upon arterial blood flow through the tissues of the leg, probably the skin, and perhaps arose from stretching or warming of abnormally sensitive nerve endings (Lewis, 1933).

Abnormalities of sweating, particularly in the feet and legs, sometimes trouble the diabetic patient and were noted by the earliest observers? The effect of body heating upon sweating, also mediated by sympathetic fibres, has frequently? been investigated in such cases; there is general agreement that the response is much diminished or absent over the legs and, in some cases, over the trunk and arms (Shumacker, 1942; Rundles, 1945 and 1950; Martin, 1953; Barany and Cooper, 1956; and others). Barany and Cooper (1956), investigating sudomotor palsy in diabetics, attempted to establish the location of the fault in the sympathetic pathway. Having demonstrated deficiency of thermally-induced sweating in the limbs of a group of diabetics (see Fig. 3), they subjected affected areas of skin to faradic current and to intradermal injection of acetylcholine. In the normal, both agents evoke axon-reflex sweating over a wide area about the stimulus, responses which are abolished by post-ganglionic section of the sympathetic fibre (Wilkins et al., 1938; Janowitz and Grossman, I950), but not by preganglionic section. In their patients sweating in response to both stimuli was reduced or absent, a deficiency which they showed was not due to atrophy of the sweat glands themselves. They also demonstrated that, in poorly sweating areas, there was abnormally prolonged piloerection following local electrophoresis of noradrenaline into the skin (Barany and Cooper, 1957). Though these findings indicate a post-ganglionic sympathetic lesion, they do not exclude the possibility of a 

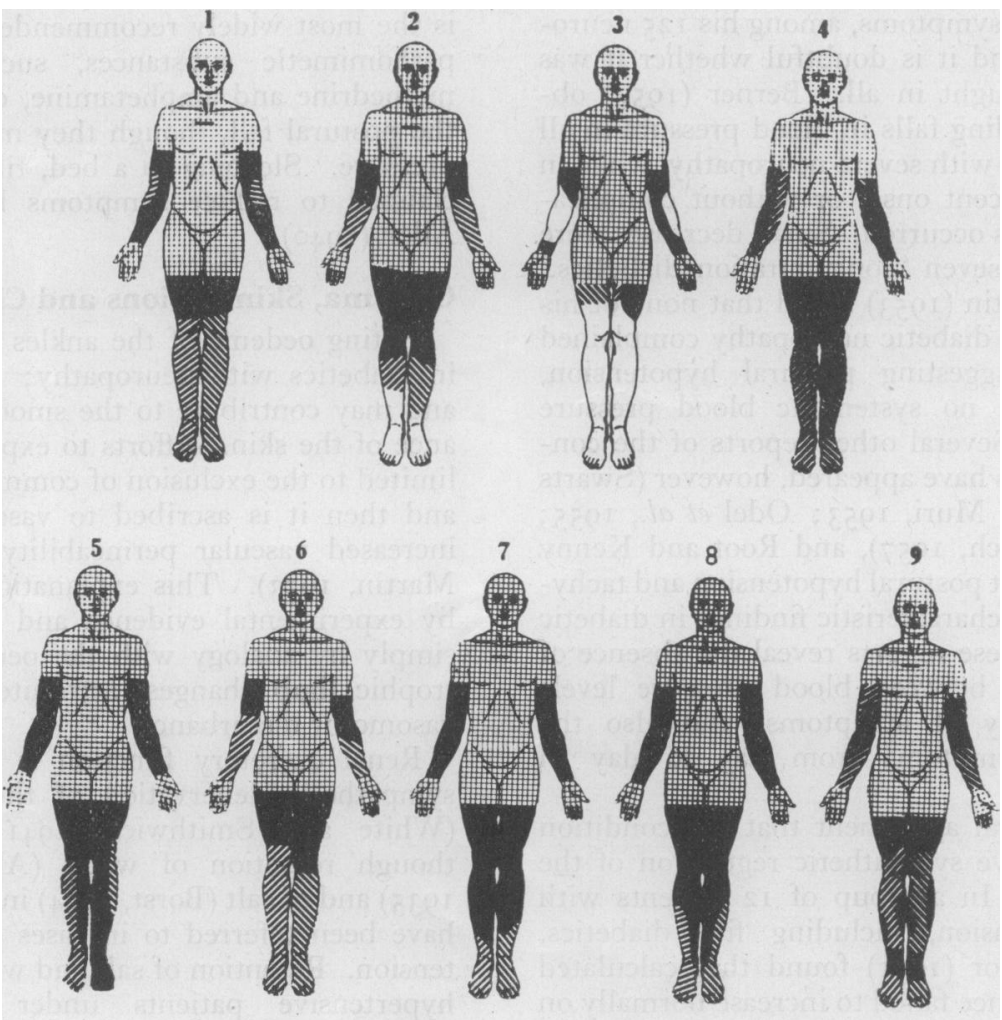

NOT EXAMINED
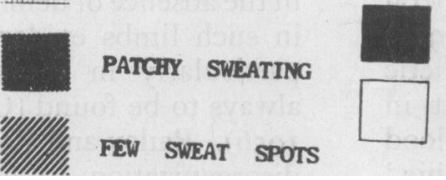

NORMAL SWEATING

NON SWEATING

FIG. 3.- Impairment of thermally-induced sweating in nine diabetics. (From Barany and Cooper, 1956; by courtesy of the Editor of Clinical Science.)

concomitant pre-ganglionic abnormality. On this point there is no published evidence, and a simple experimental approach is difficult to visualize. Histological study might prove helpful; in nerve biopsy material from diabetics with peripheral nerve disorder, Martin (1953) demonstrated degeneration, particularly of the small, poorly myelinated fibres believed to conduct sympathetic impulses. The question of a specific involvement of nerve cells and fibres within the spinal cord in diabetic neuropathy is still unsettled. Clinical (Garland and Taverner, 1953) and histological (Woltman and Wilder, 1929) evidence of myelopathy may be due to arterial disease of the cord or be the central consequences of peripheral nerve disorder. Goodman and his colleagues (1953) consider abnormalities to be confined to the peripheral nerves.

\section{Postural Hypotension}

A syndrome of profound falls in systolic and diastolic blood pressure on standing, leading to faintness and syncope, was first described by Bradbury and Eggleston (1925). They could find no cause for the failure of the normal restorative mechanisms. Subsequently, postural hypotension was described in a variety of neurological conditions (Ghrist and Brown, 1928; Ellis and Haynes, 1936; Jeffers et al., 1941; Hickam and Pryor, 195I), but it was Rundles (1945) who first clearly showed it to be a feature of diabetic neuropathy; he found eight examples of the disorder, 
five of them with symptoms, among his 125 neuropathic patients and it is doubtful whether it was systematically sought in all. Berner (1952) obtained large standing falls in blood pressure in all of seven diabetics with severe neuropathy, while in seven cases of recent onset or without complications no such falls occurred. Small decreases were found in five of seven ' long duration diabetics.' By contrast, Martin (1953) noted that none of his I 50 patients with diabetic neuropathy complained of symptoms suggesting postural hypotension, though he made no systematic blood pressure measurements. Several other reports of the condition in diabetics have appeared, however (Swarts and Stine, I948; Muri, I953; Odel et al., I955; Malins and French, 1957), and Root and Kenny (1952) remark that postural hypotension and tachycardia are ' often characteristic findings in diabetic neuropathy.' These reports reveal the absence of close correlation between blood pressure levels and the intensity of symptoms, and also the variability of symptoms from day to day in individual cases.

There is general agreement that the condition is due to defective sympathetic regulation of the blood pressure. In a group of 12 patients with postural hypotension, including five diabetics, Hickam and Pryor (I95I) found that calculated peripheral resistance failed to increase normally on standing and that there was an abnormal fall in the cardiac output. Since this fall could be reversed with large infusions of serum albumin, they inferred that it was due to slowing of venous return to the heart consequent upon failure of peripheral vasoconstriction. The work of Jeffers et al. (194I) suggested that interference with the sympathetic pathway in a number of sites could result in defective postural adjustments of the blood pressure. In three patients with 'idiopathic' postural hypotension, Verel (I95I) showed that the peripheral vasomotor nerves were intact and concluded, like others (Ellis and Haynes, I936; East and Brigden, 1946), that the abnormality lay in an autonomic centre within the central nervous system. Though Rundles (I945) favoured the same explanation in the diabetic, a defect in the peripheral autonomic pathway now seems more likely on the available evidence. The extent of the vasomotor palsy is indicated by the observation that in man sympathectomy must include section of the splanchnic nerves before postural hypotension occurs; bilateral lumbar ganglionectomy alone will not lead to the condition (White and Smithwick, 1944). To what extent, if any, the sensory baro-receptor side of the reflex arc is affected is unknown.

Treatment is disappointing. The use of puttee bandages on the legs and a tight abdominal binder is the most widely recommended measure; sympathomimetic substances, such as ephedrine, $\frac{3}{\mathbb{D}}$ methedrine and amphetamine, do little to reduce $\stackrel{ }{C}$ the postural fall, though they may raise the lying pressure. Sleeping in a bed, tilted head-up, was $\overrightarrow{\vec{F}}$ claimed to reduce symptoms by MacLean and $\overline{0}$ Allen (1940).

\section{Oedema, Skin Lesions and Charcot's Joints}

Pitting oedema of the ankles is not uncommon in diabetics with neuropathy; it is never severe and may contribute to the smooth, tense appear- $\overrightarrow{0}$ ance of the skin. Efforts to explain it are usually $\overrightarrow{\vec{\omega}}$ limited to the exclusion of common known causes, $\stackrel{\omega}{\sigma}$ and then it is ascribed to vasomotor palsy and increased vascular permeability (Rundles, 1945 ; 3 Martin, 1953). This explanation is unsupported by experimental evidence and probably evolved simply by analogy with the oedema in so-called $\underset{\omega}{0}$ trophic limb changes, attributed in the past to vasomotor disturbance.

Renal excretory function is little affected by 을 sympathetic denervation of the kidney in man $\rightarrow$ (White and Smithwick, I94I; Smith, I95I), 3 though retention of water (Alvarez and Roth, 1935) and of salt (Borst, I954) in the erect position $\overrightarrow{0}$ have been referred to in cases of postural hype् of tension. Retention of salt and water also occurs hypertensive patients under treatment with ganglion-blocking agents (Smirk, 1957).

Disorganization of the bones of the foot, and skin and soft tissue necrosis are well recognized $\frac{\circ}{\mathbb{D}}$ complications of diabetes. Both changes may occur $\stackrel{2}{\vec{z}}$ in the absence of demonstrable arterial obstruction; 윽 in such limbs evidence of neurological disorder, particularly in respect of sensation, is almost $\frac{\overrightarrow{7}}{\sigma}$ always to be found (Oakley, Catterall and Martin, 1956). Bailey and Root (1947) demonstrated joint disorganization in about $I$ in 1,000 diabetics; skin necrosis not due to arterial obstruction is much 3 . commoner, occurring in 17 of Martin's 1508 patients with neuropathy (1953).

Localized areas of skin necrosis, often with in- 0 fection and deep extension (perforating ulcer), have been dubbed 'trophic changes' and attri- $\frac{D}{2}$ buted to lesions of the sympathetic nerves. Goodman and his colleagues (1953) saw '... N impairment of the sympathetic innervation of the $N$ feet as the basic lesion responsible for trophic or N perforating ulcers,' and considered that abnormal ${ }_{\sigma}^{\omega}$ vascular reactions might lead to skin necrosis. Rundles (1945) suggested that peripheral sym- $\frac{0}{\circ}$ pathetic nerve degeneration might impair the skin's response to infection; Hirson et al. (1953) ascribed four cases of diabetic gangrene to autonomic neuropathy. It is doubtful, however, whether necrotic $\overrightarrow{\mathbb{D}}$ lesions in the skin of the feet ever arise without $\frac{?}{\mathbb{D}}$ external cause; they are situated in areas particu- $\frac{Q}{2}$ 
larly vulnerable to trauma and to pressure from shoes and calluses. Such agents are as well able to cause skin necrosis in the anaesthetic foot as they are in the unconscious patient; the addition of infection, neglect and ischaemia in older patients creates the lesions so often observed clinically. The rapid healing which follows the relief of pressure and the use of antibacterial agents and the absence of recurrence in the well-tended and well-shod foot is strong evidence of their mechanical origin.

In most cases, Biedleman and Duncan (1952) and Copland (1954) would attribute bone destruction to infection introduced through skin lesions; in some, however, neuropathy is the only detectable abnormality. Involvement of sympathetic fibres in the neuropathy does not, in itself, establish the claim that autonomic disturbance is the cause of the bone and joint degeneration (Foster and Bassett, 1947; Lister and Maudsley, I95I), as was first suggested by Charcot himself (I868). Martin's (1952) finding of normal reflex vasodilatation to heat in the legs of a tabetic with a Charcot joint suggests that the changes can occur in the absence of a sympathetic nerve lesion. Lumbar sympathectomy does not cause joint changes in the normal leg (White and Smithwick, I944), nor was it mentioned as a sequel in a report upon 93 diabetics, some with neuropathy, subjected to the operation (Berry and Flotte, 1955). In fact, Parsons and Norton (195I) claimed that lumbar sympathectomy had arrested the progress of degenerative bone changes in the feet of two diabetic patients, but this operation was without effect in a case reported by Sheppe (1953).

\section{Diabetic Diarrhoea}

Dargen and others (1936) first described the ' diarrhoea of diabetes' as a clinical entity. From subsequent descriptions (Sheridan and Bailey, 1946; Rundles, 1945; Martin, 1953; Malins and French, 1957) a characteristic clinical picture has emerged and representative examples can readily be found in most large diabetic clinics. Almost always associated with other evidence of neurological disease, the diarrhoea is intermittent, worse at nights when faecal incontinence may occur, and accompanied by borborygmi and sometimes by abdominal cramps. It may last for many years and a normal pattern of defaecation may interrupt many weeks of diarrhoea. Precipitating factors are uncertain, though Malins' study (1957) suggests that infection may start an attack. The stool is usually brown and watery and undigested food residues may be found microscopically. Steatorrhoea has been reported (Berge, 1956; Malins and French, 1957), though fat absorption may be variable (see case report I). Anaemia, osteomalacia and other features of the malabsorption syndrome have not been described.

While there is clinical evidence of abnormally rapid transit of food through the intestine (Muri, I953), radiological studies with barium present variable findings. Sheridan and Bailey (1946) could find no abnormalities of motility in 17 patients with diabetic diarrhoea, though Hodges and colleagues (1947) noted gastric retention, prolonged passage of barium through the intestinal tract, segmentation of the barium column and scattered accumulations of gas, appearances resembling those following surgical vagotomy for peptic ulcer. By contrast, Rundles (1945), Malins and French (1957) and others have found increased motility of the small intestine.

The evidence for a neurogenic cause of the diarrhoea (Marble, r940) is chiefly circumstantial, and direct proof is lacking. Associated nervous disorders are almost invariably present, particularly impotence, bladder disturbances and abnormalities of sweating; cerebrospinal fluid protein levels are often raised, sometimes grossly (Sheridan and Bailey, 1946); in two of Rundles' (r945) cases degenerative changes were demonstrated after death in the nerve trunks of the oesophageal plexus and about the coeliac ganglia. Berge, Sprague and Bennett (1956), however, could find no striking histological differences when the intrinsic nerve fibre structure, the ganglion cells of Meissner's and Auerbach's plexus, the mucosa and the muscularis from eight cases of diabetic diarrhoea were compared with similar material from 16 diabetics without diarrhoea and Io non-diabetics without intestinal disturbance. Artefacts introduced by the fixing and staining procedures may well have obscured small differences.

Although Marble (1940) and Goodman and colleagues (1953) suggested that loss of sympathetic innervation with unopposed parasympathetic action was likely to be responsible for the diarrhoea, White and Smithwick (1944) were unable to demonstrate any alteration in tone, peristalsis or sensory acuity after sympathetic denervation of the colon and rectum in man. Furthermore, diarrhoea is a well-recognized sequel of vagotomy (Hand and Patey, 1953), and the ganglion-blocking drugs, affecting both divisions of the autonomic nervous system, not uncommonly cause diarrhoea, often alternating with constipation (Smirk, 1957). The complicated functional relationship between sympathetic, parasympathetic and myenteric innervation of the intestine and inherent myogenic contractility has recently been summarized by Garry (1957); it is a reminder of the large speculative element in present-day views on the mechanism of diabetic diarrhoea. 
The dramatic clinical improvement of the diarrhoea in 16 of 22 affected patients treated with chlortetracycline reported by Malins and French (1957) led them to suggest that attacks might be precipitated by abnormal or even normal bacteria irritating a readily disturbed intestine. It contrasts strongly with Marble's (1952) warnings against long-term antibiotic treatment, which he considered might be responsible for perpetuation of the diarrhoea, though the low dose used by Malins might account for the difference. Many preparations have enjoyed a brief therapeutic vogue, but, over and above scrupulous control of the diabetes, the most promising remedies at present seem to be the tetracyclines in low dose, ephedrine in maximal dose and, to control nocturnal diarrhoea, 2.5 to $5 \mathrm{mg}$. mecamylamine at night. Needless to say, in a condition the course of which is marked by spontaneous remissions, controlled clinical trial is necessary to establish the efficacy of any therapeutic measure.

\section{Impotence}

Surprisingly little attention has been paid to the frequent occurrence of sexual impotence in diabetic males, though it has been referred to since the earliest descriptions of the disease (Naunyn, 1906; Simpson, 1949). It is commonly met with as a presenting symptom of diabetes of acute onset and usually clears completely a few weeks or months after effective diabetic treatment is started (Oakley, 1949). This is not true, however, of diabetes of insidious onset, in which hyperglycaemia may have preceded the diagnosis for many years. Impotence in these patients is usually permanent, as it is in the men who develop the condition after many years of apparently satisfactory diabetic control.

Estimates of incidence differ widely. Joslin (1946) thought impotence a rare complaint, but Oakley (1949) considered it common. Rubin and Babbott's recent survey in the U.S. (1958) disclosed that in the 30 to 35 age group one diabetic male in four is affected, and at 60 to 65,75 per cent. are impotent; these figures, however, fail to distinguish between temporary and permanent impotence. Of the 70 diabetic males with neuropathy under 60 years reported by Rundles (1945), permanent impotence was present in 38 (54 per cent.). He describes a patient with grossly defective sweating and vasomotor control in whom almost normal erection was associated with failure of ejaculation. A study of impotent males attending the Diabetic Clinic at King's College Hospital (Keen, Field and Jackson) confirms that, although failure of penile erection and ejaculation usually occur together, either may exist independently. Erection may fail quite suddenly, though more usually over a few months; it may be partial or complete. In this group manipulation of the flaccid penis can often still elicit orgasm and ejaculation and spontaneous nocturnal emissions occur. Failure of ejaculation with normal orgasm was reported by one young man; this has been ascribed to seminal reflux into the bladder, as seen sometimes after prostatectomy.

Various causes of impotence in the diabetic have been proposed. Simpson's (1950) suggestion of endarteritis is difficult to sustain in the young patient without evidence of vascular disease; Rubin and Babbott (1958) found no excess of cases with peripheral arterial disease among their impotent diabetics. There is no convincing evidence of endocrine disorder; urinary 17 -ketosteroid excretion is lower in diabetic than non-diabetic males irrespective of the degree of potency (Miller and Mason, 1945); testicular atrophy rarely occurs, and no gross abnormalities are found in testicular biopsies or sperm counts from affected males (Oakley, 1949). Psychogenic causes are rendered unlikely by the absence of early morning and masturbation erections (Rubin and Babbott, $195^{8}$ ), features distinguishing organic from psychological impotence (Simpson, I950). The diabetic is, however, no less vulnerable to anxiety than the nondiabetic and many cases of psycho-sexual impotence may be expected to occur (Strauss, 1950).

The frequent clinical association of impotence? with other visceral disorders, especially bowel and bladder disturbances, and the experimental production of similar functional losses in animals by section of the second, third and fourth sacral nerves, the nervi erigentes, strongly suggest an autonomic disorder, involvement of the parasympathetic leading to failure of erection, and of the sympathetic to loss of ejaculation (Learmonth, 1931). The following case report illustrates the dissociation between visceral and somatic neuropathy which may occur.

\section{Case Report 3 (434816)}

Male lecturer, aged 3I (r957). Patient of Dr. C. A. Young.

History. February 1953 diabetes diagnosed after few weeks' slight thirst, polyuria and weight loss. Though urine became sugar-free on carbohydrate-restricted diet without insulin, frequency of small volumes of urine, particularly at night, persisted. In April 1955, after reappearance of glycosuria, insulin was started. Soon after, patient began to pass five or six fluid stools daily; there were frequent borborygmi. For periods of days or weeks normal bowel habit returned. Also noted impairment of penile erection, which has since become complete. Readily fatigued, physically and mentally. 
During war was concentration camp inmate. Typhus 1944.

Examination. Power, all modalities of sensation, tendon reflexes and co-ordination normal in arms and legs. Bulbocavernosus reflex absent. Heart, lungs and abdomen normal. B.P. 100/70.

Investigations. Urine free of protein, pus and organisms. No crystalluria. Cystoscopy normal. No faecal pathogens found; sigmoidoscopy, barium meal and barium enema normal. No pancreatic calcification on X-ray.

Body heating revealed grossly defective sweating over whole of both legs.

Testosterone is ineffective in the treatment of established impotence, as are the $B$ group of vitamins and vitamin $B_{12}$. In a recently completed ' double-blind ' trial (Keen et al.) comparing doses of carbachol, up to $16 \mathrm{mg}$./day by mouth, with inactive placebo in I I diabetics under 50 years of age with varying grades of impotence, the slight stimulant effect of treatment in patients with partial defect was probably outweighed by its sideeffects, including sweats, flushes, colic and diarrhoea.

Serious anxiety over sexual impotence often arises both in the patient and in the wife, and discussion of the situation may help them to make the necessary emotional adjustments.

\section{Bladder Disturbances}

Recognition of neurogenic abnormalities of micturition is often delayed or missed in the diabetic, for symptoms are readily attributed to other causes. In addition to incontinence of urine (with or without retention), frequency, urgency, difficulty in starting, slowing of the stream and incomplete bladder emptying may be met with (Jordan and Crabtree, r935; Rudy and Muellner, 194I). Associated urinary infections are common and probably responsible for the haematuria occasionally reported. Spring and Hymes (1953) set the incidence of neurogenic bladder disorder at I to 2 per cent. of diabetics; one in four of Rundles' neuropathic cases was affected (ig45).

Volume-pressure relationships within the bladder have frequently been investigated and show absent or diminished sensation of distension, lowered expulsive force, increased bladder capacity and high residual volumes (Rudy and Muellner, I94I ; Rundles, I945; Martin, 1953)-an ' atonic neurogenic paralysis of the bladder ' which can be reproduced experimentally in cats by section of the posterior sacral nerve roots (Dees and Langworthy, 1935). The resemblance of the bladder disorder to that of tabes dorsalis engendered the belief that a spinal cord lesion was responsible and gave rise to the term 'the diabetic cord bladder' (Gill,
1936). Such histological findings as supported this contention (Woltman and Wilder, 1929) were derived from old subjects in whom vascular disease probably accounted for much of the pathological change. Gill (1936) found ' degenerative changes ' in the cord and posterior nerve roots of a diabetic with bladder palsy, but negative findings in a case are reported by Root and Kenny (1952). Clinical experience with the ganglion-blocking drugs has shown that disturbance of the peripheral autonomic pathway alone is adequate to produce atonic bladder palsy and that it does not necessarily indicate a lesion of the spinal cord.

Though Jordan and Crabtree (1935) presented a grim prognosis for affected patients, improvement of bladder function associated with regression of diabetic neuropathy has frequently been recorded (Rudy and Muellner, 194I; Rundles, 1945; Martin, 1952; Goodman et al., 1953). Good control of the diabetes is regarded as of prime importance in achieving this; in addition, chronic over-distension of the bladder must be avoided by catheter or suprapubic drainage, and urinary infection eradicated with antibiotics. Failing improvement after simple decompression, Emmett, Daut and Sprague (1949) recommend transurethral resection of the entire circume ference of the bladder neck and their claims of success are confirmed by others (Martin, I953\% Rundles, I945; Spring and Hymes, 1953). Aarset! (1953) reports improvement in a single case after presacral neurectomy.

\section{Gastric Retention}

References have often been made to the striking delay in stomach emptying shown radiologically in diabetics (Hodges et al., 1947; Rundles, I945; Swarts and Stine, 1948). Of its clinical counter, part relatively little is known. Rundles (1945) referred to anorexia and nausea accompanying the development of diabetic neuropathy which, in four cases, he associated with abnormally prolonged gastric retention. Bassler and Peters (1949) described a syndrome of 'diabetic indigestion' consisting of abdominal distension, belching and fluid regurgitation presenting in unrecognized and poorly controlled diabetics; unfortunately, no radiological or neurological findings are recorded. N In five of the 14 cases of diabetic diarrhoea studied $N$ by Malins and French (1957) more than one-third of the barium meal remained in the stomach after four hours. Kassander's (1958) unexpected finding of gastric retention in a diabetic led him to perform barium meal studies upon the next 25 consecutive diabetic admissions to hospital. Abnormal retention was found in five of them; in each case barium could be manually expressed through the patulous pylorus. All of his patients were men 
aged between 26 and 47 with known diabetes of from three to ro years' duration. All had anorexia of mild degree and three had intermittent diarrhoea; two were impotent; in only two was somatic neuropathy present; in some free $\mathrm{HCl}$ was found in the stomach. Recovery in several of the nine cases of delayed gastric emptying was described by Martin (I953), an outcome which he attributed to improved diabetic control. Kassander (1958), however, found that improved diabetic control, gastric aspiration and lavage, parasympathomimetic agents and vitamins all failed to ameliorate the condition.

The true incidence of the condition and its natural course is unknown; although it appears to be of little clinical consequence, it might account for unexplained fluctuations in control of insulintreated diabetics or lead to misinterpretation of the radiological findings in the investigation of vague dyspepsia in older patients.

\section{Pupillary Changes}

Abnormalities of the pupil, ranging from a sluggish light response to the typical Argyll Robertson pupil, are frequently described. Onequarter of the 150 cases with nervous disorder reported by Rundles (1945) showed some pupillary change, typically a constricted pupil responding poorly to light, but better to accommodation. Three cases, one with treated syphilis, had Argyll Robertson pupils. Also studying cases with neuropathy, Jordan (1936) found 23 out of 226 with abnormal pupils, and Martin (1953) I 3 out of 1 50. Other cases with the Argyll Robertson pupil are reported by Waite and Beetham (1935), Smith (1949), Berner (1952) and Berge (1956).

Most authorities ascribe the Argyll Robertson pupillary change to an abnormality in the midbrain, and Rundles (1945) favoured the same view in diabetics. No pathological evidence has been presented to support his thesis and both Goodman et al. (1953) and Martin (1952) present strong arguments in favour of a peripheral nerve site for the causal lesion, the latter citing the experimental production of a light-inactive but convergenceresponsive pupil by ciliary ganglionectomy in apes (Foerster et al., 1936). The return to normal of pupillary responses, noted by Rundles and others, is more suggestive of a peripheral than a central lesion; and further argument for a peripheral lesion is put forward by Duke Elder (1949), though he considers present evidence inconclusive.

\section{Conclusion}

Sufficient evidence has now accumulated to establish disease of the autonomic nervous system as a prominent feature of the neurological disorder of diabetes. Its early appearance, its widespread character and its occasional dissociation from ordinary somatic neuropathy suggest a special vulnerability of autonomic nerve fibres in the diabetic. The nature of the process remains unknown, though there seems little doubt that it is closely linked with the biochemical disturbance of diabetes itself rather than with associated vascular disease or vitamin deficiency. This common manifestation of a common disease still stands as a challenge and an invitation for idea and experiment.

\section{BIBLIOGRAPHY}

AARSETH, S. (1953), Acta. med. scand., Suppl. 281.

ALVAREZ, W. C., and ROTH, G. (1935), Proc. Mayo Clin., IO, 483 .

AUCHE, B. (1890), Arch Med. exp., 2, 635.

BAILEY, C. C., and ROOT, H. F. (1947), New Engl. F. Med., 236, 397.

BARANY, F. R. (1955), Acta med. scand., Suppl. 304.

BARANY, F. R., and COOPER, E. H. (1956), Clin. Sci., 15, 533.

BARANY, F. R., and COOPER, E. H. (1957), Ibid., 16, 275.

BARGEN, J. A., BOLLMAN, J. L., and KEPLER, E. J. (1936), Proc. Mayo Clin., II, 737.

BASSLER, A., and PETERS, A. G. (1949), Ann. intern. Med., 30, 740 .

BERGE, K. G., SPRAGUE, R. G., and BENNETT, W. A. (1956), Diabetes N.Y., 5, 289.

BERGE, K. G., WOLLAEGER, E. E, SCHOLZ, D. A., ROOKE, E. D., and SPRAGUE, R. G. (1956), Ibid., 5, 25

BERNARD, C. (1849), Mem. Soc. de biol., I (C.R.), 80.

BERNER, J. H. (1952), Acta med. scand., 143, 336.

BERRY, R. E. L., and FLOTTE, C. T. (1955), Arch. Surg. (Chicago), 7I, 460 .

BIEDLEMAN, B., and DUNCAN, G. G. (1952), Amer. F. Med., $12,43$.

BORST, J. G. G. (1954), 'Ciba Found. Symp. on The Kidney,' Churchill, London, p. 255.

BRADBURY, S., and EGGLESTON, C. (1925), Amer. Heart $\mathcal{F}$., I, 73.

CANNON, W. B., and ROSENBLUETH, A. (1949), 'The Supersensitivity of Denervated Structures: a Law of Denervation,' Macmillan, New York.

CHARCOT, M. (1868), Arch. Physiol. norm. path., x, I6r.

COLES, D. R. (1958), Personal Communication.

COOPER, K. E., and KERSLAKE, D. McK. (1953), F. Physiol. (Lond.), 119, 18.

COPLAND, W. A. (1954), Proc. roy. Soc. Med., 47, 345.

DEES, J. E., and LANGWORTHY, O. R. (1935), F. Urol. (Baltimore), 34, 359.

DUKE-ELDER, W. S. (1949), 'Textbook of Ophthalmology,' Vol. IV, Kimpton, London.

EAST, T., and BRIGDEN, W. (1946), Brit. Heart f., 8, 103.

ELLIS, L. B., and HAYNES, F. W. (1936), Arch. intern. Med., $58,773$.

EMMET, J. L., DAUT, R. V., and SPRAGUE, R. G. (1949), F. Urol. (Baltimore), 61, 224 .

FOERSTER, O., GAGEL, O., and MAHONEY, W. (1936), Verh. Dtsch. Gesellsch. Inn. Med. Kong., 48, 386.

FOSTER, D. B., and BASSETT, R. C. (1947), Arch. Neurol. Psychiat. (Chicago), 57, 173.

GARLAND, H., and TAVERNER, D. (1953), Brit. med. F., 1, 405.

GARRY, R. C. (1957), Brit. med. Bull., 13, 202.

GHRIST, D. G., and BROWN, G. E. (1928), Amer. F. med. Sci., I75, 336.

GILL, R. D. (1936), f. Urol. (Baltimore), 36, 730.

GOODMAN, J. I. (1955), Amer. F. dig. Dis., 22, 236.

GOODMAN, J. I., BAUMOEL, S., FRANKEL, L., MARCUS, L. J., and WASSERMAN, S. (1953), 'The Diabetic Neuropathies' American Lecture Series No.' 15 I, Charles C Thomas, Springfield, Illinois.

GREENFIELD, A. D. M., and SCARBOROUGH, H. (1949), Clin. Sci., 8, 211 .

HAMILTON, M., HENLEY, K. S., and MORRISON, B. (1954), Ibid., 13, 225.

Bibliography continued on page 286. 
personal service offered to the old. Undoubtedly the State does much for old people in providing what material comfort it can, and sometimes the personal touch creeps in: but it is obviously difficult for the machinery of State to provide this touch, and it is to local and voluntary efforts that we must turn. Branches and clubs may well be the means of contributing very largely to the relief of distress in the aged diabetic.
Old age can be a time of great unhappiness or of calm and contentment. These states are not en⿳亠丷厂 tirely dependent on physical health but may oftem be due to the withholding or giving of loving care. We must do all we can to help from the materiat. angle but, and this is important, we must also give that extra loving kindness which will do so muct to ensure a peaceful Indian summer for the age diabetic.

Bibliography continued from page $26_{5}-D$. A. Pyke, M.D., M.R.C.P.

HURWITZ, D., and JENSEN, D. (1946), New England F. Med., 234, 327.

JACKSON, W. P. U. (1955), Lancet, ii, 625.

JOHNSON, D. G., and BONSNES, R. W. (1948), F. clin. Invest., 27, 145 .

JOSLIN, E. P. (1952), in 'The Treatment of Diabetes,' London.

KEEN, H. (1957), Paper read to Banting Memorial Meeting of the British Diabetic Association, Oxford.

KEMSLEY, W. F. F. (1950), Ann. Eugen. (Lond.), 15, 161.

KEMSLEY, W. F. F. (1952), Ibid., 16, 316.

KRISS, J. P., and FUTCHER, P. H. (1948), f. clin. Endocr., 8, 380.

MOSENTHAL, H. O., and BOLDUAN, C. (1933), Amer. Y. med. Sci., 186, 605.

MUNRO, H. N., EATON, J. C., and GLEN, A. (1949), f. clin. Endocr., 9, 48.

PINCUS, G., and WHITE, P. (1933), Amer. F. med. Sci., 186, I.
PINCUS, G., and WHITE, P. (1934a), Ibid., 188, 159. PINCUS, G., and WHITE, P. (1934b), Ibid., 188, 782. PYKE, D. A. (1956), Lancet, i, 818.

PYKE, D. A., and PLEASE, N. W. (1957), f. Endocr., 15, xxvT PYKE, D. A., and WATTLEY, G. H. (1958), unpublishe⿳亠二口犬

observations.
SEGI, M. (1956), 'Statistical Report on Patients in Tohok University Hospital, 1953-54,' Sendai, Japan.

STEINBERG, A. G. (1958), Diabetes, 7, 244.

THOMPSON, M. W., LAAKSO, L. E., and WATSON, E. Ni (1950), Canadian med. Ass. F., 63, 556.

TOMBLESON, S. B. (1954), N.Z. med. f., 53, 230.

WATSON, E. M., and THOMPSON, M. W. (1951), Amer. dig. Dis., 18, 326.

World Health Organization (W.H.O.) (1955), 'Annual Epidemio logical and Vital Statistics, 1952.

Bibliography continued from page 280-Harry Keen, M.B., M.R.C.P.

HAND, B. H., and PATEY, D. H. (1953), Brit. F. Surg., 41, I6r. HANDELSMAN, M. B., LEVITT, L. M., and CONRAD, $H$. (1952), Amer. F. med.' Sci., 224, 34.

HICKAM, J. B., and PRYOR, W. W. (1951), F. clin. Invest., 30, 401 .

HIRSON, C., FEINMANN, E. L., and WADE, H. J. (1953), Brit. med. F., i, 1408 .

HODGES, F. R., RUNDLES, R. W., and HANELIN, J. (1947), Radiology, 49, 659 .

JANOWITZ, H. D., and GROSSMAN, M. I. (1950), F. invest. Derm., 14, 453.

JEFFERS, W. A., MONTGOMERY, H., and BURTON, A. C. (1941), Amer. F. med. Sci., 202, I.

JORDAN, W. R. (1936), Arch. intern. Med., 57, 307.

JORDAN, W. R., and CRABTREE, H. H. (1935), Ibid., 55, 17.

KASSANDER, P. (1958), Ann. intern. Med., 48, 797.

KEEN, H., FIELD, J. B., and JACKSON, D., to be published.

KERSLAKE, D. McK., and COOPER, K. E. (1950), Clin. Sci., 9, $3 \mathbf{I}$.

LEARMONTH, J. R. (I93I), Brain, 54, 147.

LEWIS, T. (1933), Clin. Sci., r, 175.

LISTER, J., and MAUDSLEY, R. H. (1951), Lancet, ii, I, I 10.

MACLEAN, E. R., and ALLEN, E. V. (1940), Ұ. Amer. Med. Ass., $115,2,162$.

MALINS, J. M., and FRENCH, J. M. (1957), Quart. f. Med., 26, 467 .

MARBLE, A. (1940), in ' Treatment of Diabetes Mellitus,' 7th Ed., Lea and Febiger, Philadelphia.

MARBLE, A. (1952), Ibid., 9th Ed.

MARTIN, M. M. (1952), 'M.D. Thesis,' Univ., Durham.

MARTIN, M. M. (1953), Lancet, i, 560.

MARTIN, M. M. (1953), Brain, 76, 594.

MEGIBOW, R. S., MEGIBOW, S. J., POLLACK, H., BOOKMAN, J. J., and OSSERMAN, K. (1953), Amer. $\mathcal{F}$. Med., 15, 322.

MENDLOWITZ, M., GROSSMAN, E. B., and ALPERT, S. (1953), Ibid., 15,316

MURI, J. W. (1953), Acta med. scand., 146, 143.

NAUNY, B. N. (1906), in 'Der Diabetes Mellitus,' and Ed., Holder, Vienna.

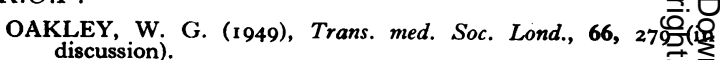

OAKLEY, W., CATTERALL, R. C. F., and MARTIN, M. NG (1956), Lancet, ii, 953. ODEL, H. M., ROTH, G. M., and KEATING, F. R. (I95悉
Diabetes, 4, 92 .

PARSONS, H., and NORTON, W. S. (r95I), New Engl. Y. Med 244, 935 .

PAVY, W. F. (1885), Lancet, ii, 1,033 and $\mathrm{r}, 085$.

PICKERING, Sir G. W. (r958), Ibid., i, I and 59.

ROOT, H. F., and KENNY, A. J. (r952), in ' Treatment of Diabetes Mellitus,' 9 th Ed., Lea and Febiger, Philadelphia.

RUBIN, A., and BABBOTT, D. (1958), F. Amer. med. Ass., r68 498.

RUDY, A., and MUELLNER, R. S. (194I), F. Urol (Baltimoref 45,844 .

RUNDLES, R. W. (1945), Medicine (Baltimore), 24, I I I.

RUNDLES, R. W. (1950), Bull. N.Y. Acad. Med., 26, 598.

SHEPPE, W. M. (1953), Ann. intern. Med., 39, 625.

SHERIDAN, E. P., and BAILEY, C. C. (I946), 7 Amer med Ass I30, 623 .

SHUMACKER, H. B. (1942), Bull. Fohns Hopk. Hosp., 71, I.

SHUMAN, C. R., and GILPIN, S. F. (1954), Amer. F. med. ScII 227, 612.

SIMPSON, S. L. (1950), Brit. med. F., i, 692.

SMIRK, F. H. (1957), ' High Arterial Pressure,' Blackwell Scientiff Publications, Oxford.

SMITH, H. W. ( 195 I), 'The Kidney,' Oxford University Press.

SMITH, M. D. (1949), Glasg. med. F., 30, 18 I.

SPRING, M., and HYMES, J. (1953), Diabetes, 2, 199.

STRAUSS, E. B. (1950), Brit. med. F., i, 697

SWARTS, J. M., and STINE, L. A. (1948), Amer. F. Med., 5, 6ro

VEREL, D. (195I), Brit. Heart F., 13, 6r.

WAFTE, J. H., and BEETHAM, W. P. (1935), New Engl. F. Med 212, $367,429$.

WHITE, J. C., and SMITHWICK, R. H. (1944), 'The Autonomi Nervous System,' 2nd Ed., Kimpton, London. WILKINS, R. W., NEWMAN, H. W., and DOUPE, J. (1939
Brain, 6I, 290.

WOLTMAN, H. W., and WILDER, R. M. (1929), Arch. inters Med., $44,576$. 